\title{
Potential antimalarial activity of Methyl Jasmonate and its effect on lipid profiles in Plasmodium Berghei infected mice
}

\author{
Oladapo. E. Oyinloye ${ }^{1}$, Ayokulehin .M. Kosoko², Benjamin Emikpe ${ }^{3}$, \\ Catherine. O. Falade ${ }^{1}$, Olusegun .G. Ademowo ${ }^{4}$
}

1. University of Ibadan, Department of Pharmacology and Therapeutics, College of Medicine

2. University of Ibadan, Department of Biochemistry

3. University of Ibadan, Department of Veterinary Pathology

4. University of Ibadan, Institute for Advanced Medical Research and Training (IAMRAT), College of Medicine

\begin{abstract}
Background: The antimalarial activity and lipid profiles of Methyl Jasmonate (MJ) were investigated against established malaria infection in vivo using $\mathrm{BALB} / \mathrm{c}$ mice.

Methods: Arteether (AE) and chloroquine (CQ) were used as reference drugs while ethanol was used as the vehicle for drug delivery for MJ.

Results: Mice treated with 10 and $25 \mathrm{mg} / \mathrm{kg} \mathrm{MJ}$ showed a remarkable reduction in percentage parasitemia by $68.3 \%$ and $78.2 \%$ on day 10 (post treatment) respectively while $45.4 \%$ and $87.2 \%$ reduction in percentage parasitemia were observed in the group treated with $50 \mathrm{mg} / \mathrm{kg}$ on day 3 and 10 (post treatment) respectively. The highest mean survival time was observed in CQ followed by AE and MJ in dose-dependent manner. A progressive decrease in packed cell volume (PCV) was observed in infected untreated mice which led to the death of all the mice by day 9 (post treatment). Infected mice treated with MJ showed reduced level of HDL and LDL compared with infected untreated group. As the dose of MJ increased in infected mice cholesterol levels increased while there was reduction in triglyceride.

Conclusion: Overall there was marked decrease in parasitemia in Plasmodium berghei infected mice treated with graded doses of MJ but appears to have reduced antimalarial activity compared with CQ and AE.

Keywords: Antimalarial activity, Lipid profile, Methyl jasmonate, Mice, Plasmodium berghei.

DOI: http://dx.doi.org/10.4314/ahs.v15i3.19

Cite as: Oyinloye OE, Kosoko AM, Emikpe B, Falade CO, Ademowo OG. Potential antimalarial activity of Methyl Jasmonate and its effect on lipid profiles in Plasmodium Berghei infected mice. Afri Health Sci. 2015;15(3):841-50. doi: http:/ / dx.doi.org/10.4314/ abs.v15i3.19
\end{abstract}

\section{Introduction}

Malaria is a major threat to public health and economic development in Africa .Current estimates indicate that at least one million children die of malaria each year in Africa alone. ${ }^{1}$ Efforts at eradicating malaria have failed as parasite resistance to the most commonly used and affordable antimalarial drugs are developing rapidly. ${ }^{1}$ There is need for discovery of new drugs for the treatment of P. falciparum malaria which should be efficacious against drug-resistant strains, provide cure within

\footnotetext{
Corresponding author:

Oladapo. E. Oyinloye

University of Ibadan, Department of

Pharmacology and Therapeutics,

College of Medicine

Email: dapobuk2003@yahoo.com
}

a reasonable time (ideally three days or less) safe, suitable for children and pregnant women, have appropriate formulations for oral use and above all, be affordable. ${ }^{2}$ As part of the effort at discovering new antimalarial agents, we evaluated on Methyl Jasmonate, a plant hormone for its therapeutic effect. Methyl jasmonate has been known since 1962 as a fragrant component in the essential oil from flowers of jasmine, Jasminium grandiflorum. ${ }^{3}$ The result of an in vitro study demonstrated the antiparasitic potential of Jasmonates using two major human blood parasites, Plasmodium falciparum and Schistosma mansoni. ${ }^{4}$ Other studies also showed that Methyl Jasmonate (MJ) exhibited anticancer activity in vitro and in vivo. ${ }^{5-7}$

In this study, we evaluated possible in vivo antimalarial activity of $\mathrm{MJ}$ and its effect on lipid profiles in mice infected with Plasmodium berghei.

\section{Materials \\ Chemicals}

Methyl Jasmonate (MJ) was obtained from SERVA 
(Herdelberg). It was dissolved in 95\% ethanol. Chloroquine and artheether were obtained from Laborate Pharmaceutical (India) and IPCA (India) respectively. Triglyceride and cholesterol kits were obtained from Vital Diagnostic Spb Ltd, Russia, HDL-cholesterol kit was obtained from Randox Laboratories Ltd United Kingdom while alanine aminotransaminase (ALT), aspartate aminotransaminase (AST), and alkaline phosphatase (ALP) kits were obtained from Vital Diagnostic Spb Ltd, Russia. All other reagents were of analytical grade and purest quality available.

\section{Method}

\section{Animals and parasite}

Seventy BALB/c mice were obtained from the animal house of the Institute of Advanced Medical Research and Training (IAMRAT), College of Medicine, University of Ibadan, Nigeria. The animals were housed in group of seven mice per cage, fed with standard mouse cubes (Ladokun feeds, Nigeria, Ltd) and supplied with clean drinking water ad libitum. P. berghei NK 65 (chloroquine sensitive) used in this study was a donation to the laboratory of one of us (AOG) by Malaria Research and Reference Reagent Resource centre (MR4) USA. The parasites were maintained in animals by serial blood passages in mice.

\section{Study of the course of infection and antimalarial activity}

The course of infection following intraperitoneal inoculation of mice was studied in each experimental mouse that received $1 \times 10^{7}$ parasitized red blood cells in $0.2 \mathrm{ml}$ inoculums. Thin films were made from the tail vein of infected mice, fixed with methanol and stained with $10 \%$ Giemsa stain using standard procedure. Parasitemia was monitored daily and screened under $\mathrm{X}$ 1000 magnification using a light microscope. Treatment commenced when parasitemia was established (about $10 \%$ ). In vivo antimalarial activity against $P$. berghei infection in mice was monitored according to Rane's test as described by Elufioye et al. ${ }^{8}$ The Rane's test relies on the ability of standard inoculum of $P$. berghei to kill the recipient mouse within 12 days of inoculation. Extension of survival beyond 12 days is regarded as activity.

\section{Study design}

Mice weighing between 18 and $30 \mathrm{~g}$ were distributed into 10 groups of seven animals each. Four groups of animals were uninfected; one group received the vehicle only $(0.3 \mathrm{ml}$ ethanol) and served as normal uninfected control group, while the three other uninfected groups received 10, 25 and $50 \mathrm{mg} / \mathrm{kg}$ body weight MJ respectively once daily for four consecutive days. Six groups were infected with Plasmodium berghei (NK 65 strain); one group was not treated while the remaining five groups were treated with $3 \mathrm{mg} / \mathrm{kg}$ arteether (AE), 10 $\mathrm{mg} / \mathrm{kg}$ chloroquine (CQ), and MJ 10, 25 and $50 \mathrm{mg} /$ $\mathrm{kg}$ body weight respectively. The groups that received $\mathrm{AE}$ and CQ were administered standard doses for three consecutive days while those groups that received MJ were treated for four consecutive days after infection was established. All administration was by oral gavage. Thin films were made from the blood collected from the tail of infected mice for the first 7 days to determine the percentage parasitemia. Films were made weekly for 28 days. The mice were sacrificed 24 hours after the administration of the last treatment (D4). All the procedures and the protocol conformed to the guidelines of the National Institute of Health $(\mathrm{NIH})$ publication $85-23,1985)$ for laboratory animal care and use. Two milliliter of blood was collected into plain bottles, centrifuged for 10 minutes at 3,000g using bench centrifuge and serum were collected to determine ALT, AST, and ALP activities, total cholesterol, triglyceride and high density lipoprotein- cholesterol (HDL-Cholesterol) levels. Liver, kidney and brain tissues were collected into test tubes containing $10 \%$ formalin stored at $4^{\circ} \mathrm{C}$ for histopathological examination.

\section{Biochemical assays}

In vitro quantitative determination of ALT, AST and ALP activities, total cholesterol and triglyceride levels in the serum were determined using Vital Diagnostics Spb Ltd kits while RANDOX Laboratories Ltd kit was used to determine high density lipoprotein- cholesterol (HDL-Cholesterol) level. The activities of ALT and AST were determined using Kinetic UV method (IFCC modification). The method is based on change in spectral absorption of NADH when converted to NAD. ALP activity was determined using End point method which is based on the formation of p-nitrophenol after increase in spectral absorption. The p-nitrophenol formed was proportional to the alkaline phosphate activity in the sample. Cholesterol level was determined by hydrolyses of cholesterol esters to free cholesterol by cholesterol esterase and resulted to red quinoneimine production. Triglyceride level was assayed by the chromagen production which is directly proportional to concentration of triglyceride. Supernatant fraction of cholesterol was used to determine HDL-cholesterol 
using enzymatic method. LDL-cholesterol was determined using Friedewald's formula.?

\section{Statistical analysis}

The results were expressed as mean \pm standard deviation (SD) of seven mice per group. Data was analyzed by one-way analysis of variance (ANOVA) followed by post hoc Duncan's multiple range test using SPSS version (15.0) statistical software. Level of significant differences was set at $\mathrm{p}<0.05$.

\section{Results}

A progressive increase in percentage parasitemia was observed in infected untreated mice with maximum of
$177 \%$ increase by day 3 (post treatment) which led to the mice death. AE and CQ gave maximum response in parasitemia reduction on day 3 (post treatment) by $90 \%$ and $91.9 \%$ respectively while parasitemia reduction on day 3 (post treatment) in $50 \mathrm{mg}$ MJ treated group was $45.4 \%$. The maximum percentage reduction in parasitemia was obtained on day10 (post treatment) with $87.2 \%, 78.4 \%$ and $68.3 \%$ in 50, 25 and $10 \mathrm{mg} / \mathrm{kg} \mathrm{MJ}$ treated groups respectively. Mean survival time for infected untreated group was significantly reduced due to the $P$. berghe i infection, while a doubling effect was observed for AE, CQ and MJ treated groups when compared with infected untreated group (Table 1),(Fig 1).

\section{Table 1: Mean survival time of infected treated and infected untreated animals}

$\begin{array}{ll}\text { Treatments Groups } & \text { Days } \\ \text { Infected untreated (IU) } & 9.3 \pm 4.9 \\ P+A E & 27.2 \pm 2.3 \\ P+C Q & 31.5 \pm 2.5 \\ P+M J(10 \mathrm{mg}) & 21.6 \pm 3.4 \\ P+M J(25 \mathrm{mg}) & 22.3 \pm 3.1 \\ P+M J(50 \mathrm{mg}) & 22.6 \pm 2.9\end{array}$

Values are reported as mean $(n=7)$

$\mathrm{IU}=$ Infected-untreated animals, $\mathrm{P}+\mathrm{CQ}=$ P. berghei Infected animals - treated with $10 \mathrm{mg} / \mathrm{kg}$ chloroquine, $\mathrm{P}+\mathrm{AE}=$ $P$. berghei infected animlas-treated with $3 \mathrm{mg} / \mathrm{kg}$ arteether, $\mathrm{P}+\mathrm{MJ}(10 \mathrm{mg})=P$.berghei infected animals-treated with $10 \mathrm{mg} / \mathrm{kg}$ methyl jasmonate, $\mathrm{P}+\mathrm{MJ}(25 \mathrm{mg})=P$. berghei infected animals- treated with $25 \mathrm{mg} / \mathrm{kg}$ methi jasmonate, $\mathrm{P}+\mathrm{MJ}$ $(50 \mathrm{mg})=P$.berghei infected animals-treated with $50 \mathrm{mg} / \mathrm{kg}$ methiyl jasmonate.

\section{Figure 1 Effect of treatment on percentage parasitaemia}

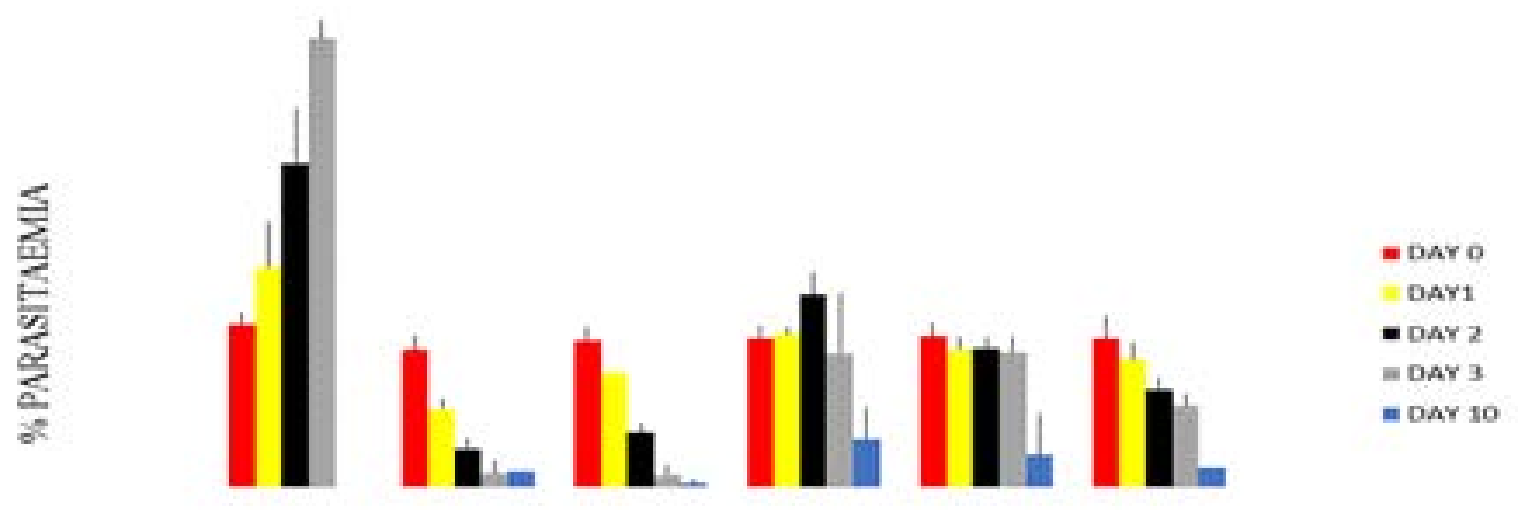

TREATMENTS

$\mathrm{IU}=$ infected - untreated animals, $\mathrm{P}+\mathrm{CQ}=\mathrm{P}$ berghei infected animals - treated with $10 \mathrm{mg} / \mathrm{kg}$ chloroquine, $\mathrm{P}+\mathrm{AE}=\mathrm{P} . \mathrm{berghei}$ infected animals - treated with $3 \mathrm{mg} / \mathrm{kg}$ arteether, $\mathrm{P}+\mathrm{MJ}(10 \mathrm{mg})=\mathrm{P}$. berghei infected animals - treated with $10 \mathrm{mg} / \mathrm{kg} \mathrm{methyl} \mathrm{jasmonate}$, $\mathrm{P}+\mathrm{MJ}(25 \mathrm{mg})=\mathrm{P}$.berghei infected animals - treated with $25 \mathrm{mg} / \mathrm{kg}$ methyl jasmonate, $\mathrm{P}+\mathrm{MJ}(50 \mathrm{mg})=\mathrm{P}$. berghei infected animals - treated with $50 \mathrm{mg} / \mathrm{kg}$ methyl jasmonate. Note that all animals in the infected untreated had died by day 10 . 
As expected a decrease in parked cell volume (PCV) was observed in infected untreated mice as percentage parasitemia increased. The PCV of groups treated with
$\mathrm{AE}$ and CQ were not reduced markedly when compared with infected untreated and MJ treated groups. (Table 2)

Table 2: Effect of MJ, AE, and CQ treatments on packed cell volume (PCV) in P. berghei infected and uninfected mice

\begin{tabular}{|c|c|c|c|c|c|c|c|c|c|c|}
\hline Days & $\begin{array}{c}\text { Infected } \\
\text { untreated (IU) }\end{array}$ & $P+A E$ & $P+C Q$ & P+10mg MJ & $\mathrm{P}+25 \mathrm{mg} \mathrm{MJ}$ & P+50mg MJ & control & $10 \mathrm{mg} \mathrm{MJ}$ & $25 \mathrm{mg} \mathrm{MJ}$ & $50 \mathrm{mg} \mathrm{MJ}$ \\
\hline 0 & $50 \pm 3.6$ & $46.6 \pm 3.3$ & $42.8 \pm 5.6$ & $49 \pm 4.2$ & $47 \pm 10.5$ & $49.8 \pm 3.3$ & $51.4 \pm 3.1$ & $47 \pm 2.7$ & $49.6 \pm 0.9$ & $48 \pm 3.1$ \\
\hline 7 & $41.5 \pm 2.5$ & $40.6 \pm 3.7$ & $37.8 \pm 5.6$ & $40.2 \pm 3.3$ & $44.6 \pm 6.9$ & $46.2 \pm 4.7$ & $51.4 \pm 3.1$ & $48.6 \pm 1.9$ & $49.2 \pm 1.3$ & $48 \pm 3.1$ \\
\hline 8 & $33.6 \pm 3.6 *$ & $42.2 \pm 2.1$ & $38.2 \pm 4.7$ & $37 \pm 2.2$ & $41.4 \pm 5.3$ & $40.6 \pm 9$ & $50.6 \pm 1.3$ & $48.2 \pm 2.5$ & $50 \pm 0.00$ & $48.2 \pm 3.3$ \\
\hline 9 & $29.6 \pm 5.2^{*}$ & $43.8 \pm 3.6$ & $41.1 \pm 3.2$ & $33.4 \pm 2$ & $35.6 \pm 4.7$ & $38.2 \pm 7.3$ & $50.6 \pm 1.3$ & $48.2 \pm 2.5$ & $49 \pm 2.2$ & $47.4 \pm 4$ \\
\hline 10 & $22.8 \pm 5.9 *$ & $47.4 \pm 4$ & $43.3 \pm 4.6$ & $28.4 \pm 3 *$ & $32.8 \pm 6.4$ & $35.4 \pm 8.3$ & $50.6 \pm 1.3$ & $47.8 \pm 3.0$ & $49.4 \pm 2.5$ & $47.6 \pm 4$ \\
\hline
\end{tabular}

Values are reported as mean \pm S.D. $(n=7)^{*}=$ Significant when compared with base line PCV on day 0

Asterisk indicate, significant difference from infected untreated $(\mathrm{p}<0.05) ; \mathrm{IU}=P$. berghei infected - untreated animals, $\mathrm{P}+\mathrm{CQ}=P$. berghei infected animals - treated with $10 \mathrm{mg} / \mathrm{kg}$ chloroquine, $\mathrm{P}+$ $\mathrm{AE}=P$. berghei infected animals - treated with $3 \mathrm{mg} / \mathrm{kg}$ arteether, $\mathrm{P}+\mathrm{MJ}(10 \mathrm{mg})=P$. berghei infected animals - treated with $10 \mathrm{mg} / \mathrm{kg}$ methyl jasmonate, $\mathrm{P}+\mathrm{MJ}(25 \mathrm{mg})=P$. berghei infected animals - treated with $25 \mathrm{mg} / \mathrm{kg}$ methyl jasmonate, $P+\mathrm{MJ}(50 \mathrm{mg})=P$. berghei infected animals - treated with $50 \mathrm{mg} / \mathrm{kg}$ methyl jasmonate , control - administered with ethanol, $\mathrm{M} \mathrm{J}(10 \mathrm{mg}), \mathrm{MJ}$ $(25 \mathrm{mg})$ and $\mathrm{MJ}(50 \mathrm{mg} / \mathrm{kg})=$ uninfected animals administered with $10 \mathrm{mg}, 25 \mathrm{mg}$ and $50 \mathrm{mg} / \mathrm{kg}$ methyl jasmonate, day $7,8,9$ and $10=$ post infection

ALT and AST activity in infected untreated group increased relative to normal control (Fig 2). CQ and AE inhibited the increase caused by $P$. beghei infection while MJ on the other hand inhibited the increase in AST levels but had no effect on ALT (Fig 2). 


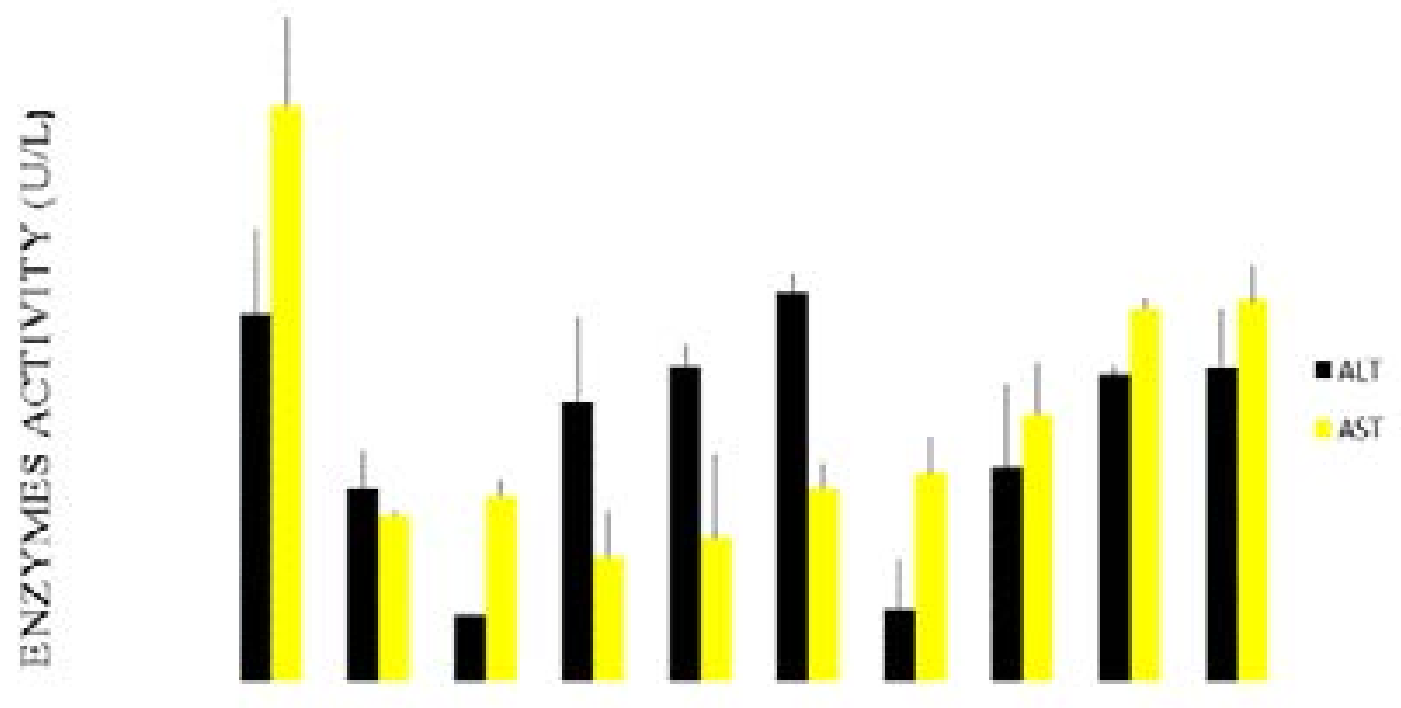

TREATMENTS

$\mathrm{IU}=P$. berghei infected - untreated animals, $\mathrm{P}+\mathrm{CQ}=P$. berghei infected animals - treated with $10 \mathrm{mg} / \mathrm{kg}$ chloroquine, $\mathrm{P}+\mathrm{AE}=P$. berghei infected animals - treated with $3 \mathrm{mg} / \mathrm{kg}$ arteether, $\mathrm{P}+\mathrm{MJ}(10 \mathrm{mg})=P$. berghei infected animals treated with $10 \mathrm{mg} / \mathrm{kg}$ methyl jasmonate, $\mathrm{P}+\mathrm{MJ}(25 \mathrm{mg})=P$. berghei infected animals - treated with $25 \mathrm{mg} / \mathrm{kg}$ methyl jasmonate, $\mathrm{P}+\mathrm{MJ}(50 \mathrm{mg})=P$. berghei infected animals - treated with $50 \mathrm{mg} / \mathrm{kg}$ methyl jasmonate , control administered with ethanol, M J $(10 \mathrm{mg})$, MJ $(25 \mathrm{mg})$ and $\mathrm{MJ}(50 \mathrm{mg} / \mathrm{kg})=$ uninfected animals administered with $10 \mathrm{mg}, 25 \mathrm{mg}$ and $50 \mathrm{mg} / \mathrm{kg}$ methyl jasmonate

It was observed that there was increase in ALT and AST activity in uninfected group administered with MJ relative to control(fig 2). Although there was elevation in ALT and AST in uninfected animals administered with MJ but the elevation was not significant $(p>0.05)$ when compared with infected untreated animals relative to control (Fig 2). ALP in infected untreated group increased markedly compared with infected treated and control groups (Fig 3). 


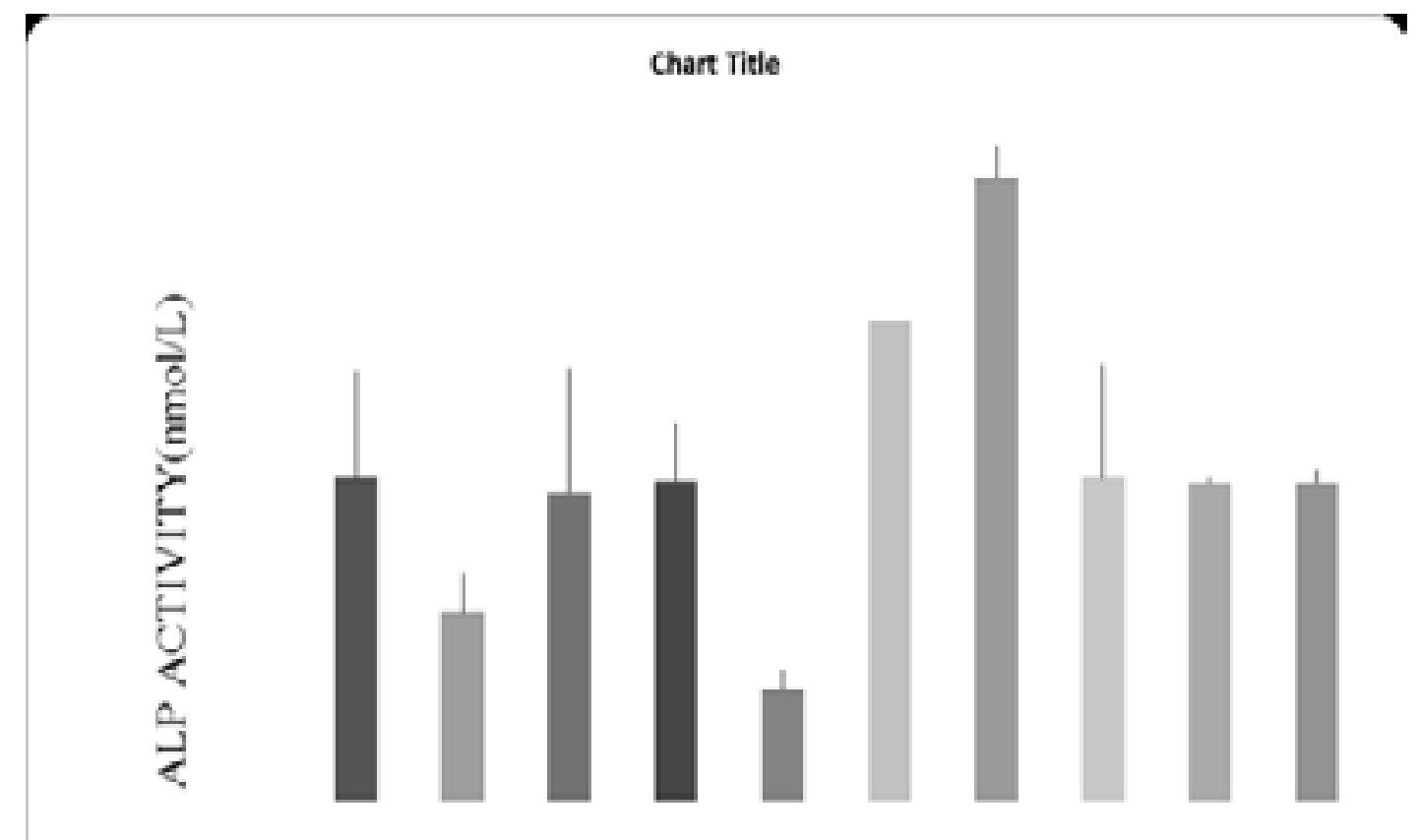

$\mathrm{IU}=P$. berghei infected - untreated animals, $\mathrm{P}+\mathrm{CQ}=P$. berghei infected animals - treated with $10 \mathrm{mg} / \mathrm{kg}$ chloroquine, $\mathrm{P}+\mathrm{AE}=P$. berghei infected animals - treated with $3 \mathrm{mg} / \mathrm{kg}$ arteether, $\mathrm{P}+\mathrm{MJ}(10 \mathrm{mg})=P$. berghei infected animals treated with $10 \mathrm{mg} / \mathrm{kg}$ methyl jasmonate, $\mathrm{P}+\mathrm{MJ}(25 \mathrm{mg})=P$. berghei infected animals - treated with $25 \mathrm{mg} / \mathrm{kg}$ methyl jasmonate, $\mathrm{P}+\mathrm{MJ}(50 \mathrm{mg})=P$. berghei infected animals - treated with $50 \mathrm{mg} / \mathrm{kg}$ methyl jasmonate , control administered with ethanol, M J $(10 \mathrm{mg})$, MJ $(25 \mathrm{mg})$ and $\mathrm{MJ}(50 \mathrm{mg} / \mathrm{kg})=$ uninfected animals administered with $10 \mathrm{mg}, 25 \mathrm{mg}$ and $50 \mathrm{mg} / \mathrm{kg}$ methyl jasmonate

Infected untreated group had the highest level of HDL and LDL compared with infected groups treated with either AE, CQ and MJ, uninfected and control group (Fig 4). An increase in HDL and LDL was observed in groups administered with $\mathrm{MJ}$ in both infected and uninfected animals relative to control (Fig 4). An in- crease in cholesterol was observed in the groups treated with MJ compared with control but triglyceride levels were similar in MJ treated groups and control. Infected group treated with $\mathrm{AE}$ showed a significant increase $(\mathrm{p}$ $<0.05)$ in cholesterol and triglyceride in comparison to control (Fig 4). 


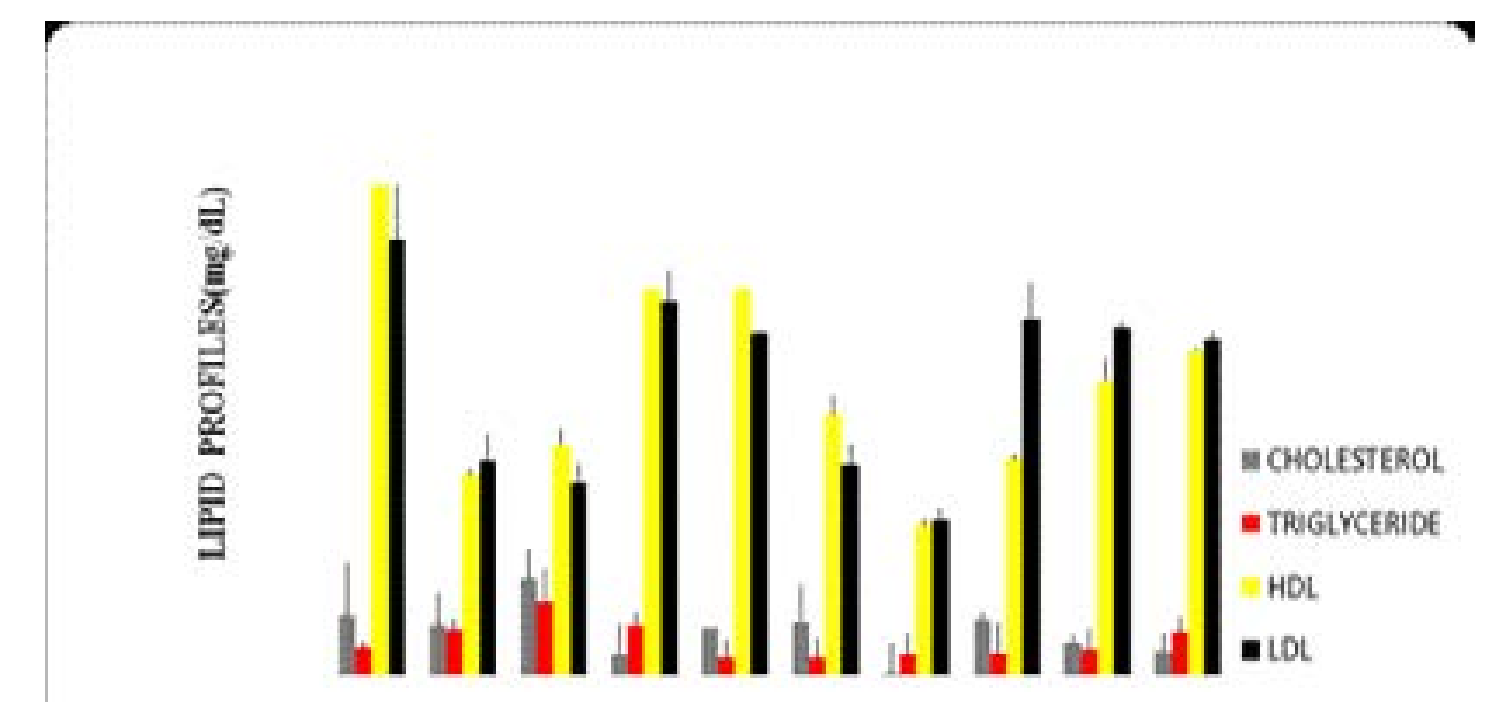

$\mathrm{IU}=P$. berghei infected - untreated animals, $\mathrm{P}+\mathrm{CQ}=P$. berghei infected animals - treated with $10 \mathrm{mg} / \mathrm{kg}$ chloroquine, $\mathrm{P}+\mathrm{AE}=P$. berghei infected animals - treated with $3 \mathrm{mg} / \mathrm{kg}$ arteether, $\mathrm{P}+\mathrm{MJ}(10 \mathrm{mg})=P$. berghei infected animals treated with $10 \mathrm{mg} / \mathrm{kg}$ methyl jasmonate, $\mathrm{P}+\mathrm{MJ}(25 \mathrm{mg})=P$. berghei infected animals - treated with $25 \mathrm{mg} / \mathrm{kg}$ methyl jasmonate, $\mathrm{P}+\mathrm{MJ}(50 \mathrm{mg})=P$. berghei infected animals - treated with $50 \mathrm{mg} / \mathrm{kg}$ methyl jasmonate , control administered with ethanol, M J $(10 \mathrm{mg})$, MJ $(25 \mathrm{mg})$ and $\mathrm{MJ}(50 \mathrm{mg} / \mathrm{kg})=$ uninfected animals administered with $10 \mathrm{mg}, 25 \mathrm{mg}$ and $50 \mathrm{mg} / \mathrm{kg}$ methyl jasmonate

No significant changes in histology of the brain was observed in all the groups relative to control.The kidney of treated and untreated mice were normal except for P. berghei infected mice treated with CQ that showed presence of protein cast (Fig $5\{a\}$ ).
Perivascular mononuclear cell infiltration occured in the liver of all $P$. berghei infected mice treated and untreated ( Fig $5\{b\}$ ), while necrosis was observed in the liver of infected untreated mice (Fig $5\{c\}$ ).

Discussion

\section{Figure 5 (a) Effect of chloroquine treatment in kidney}

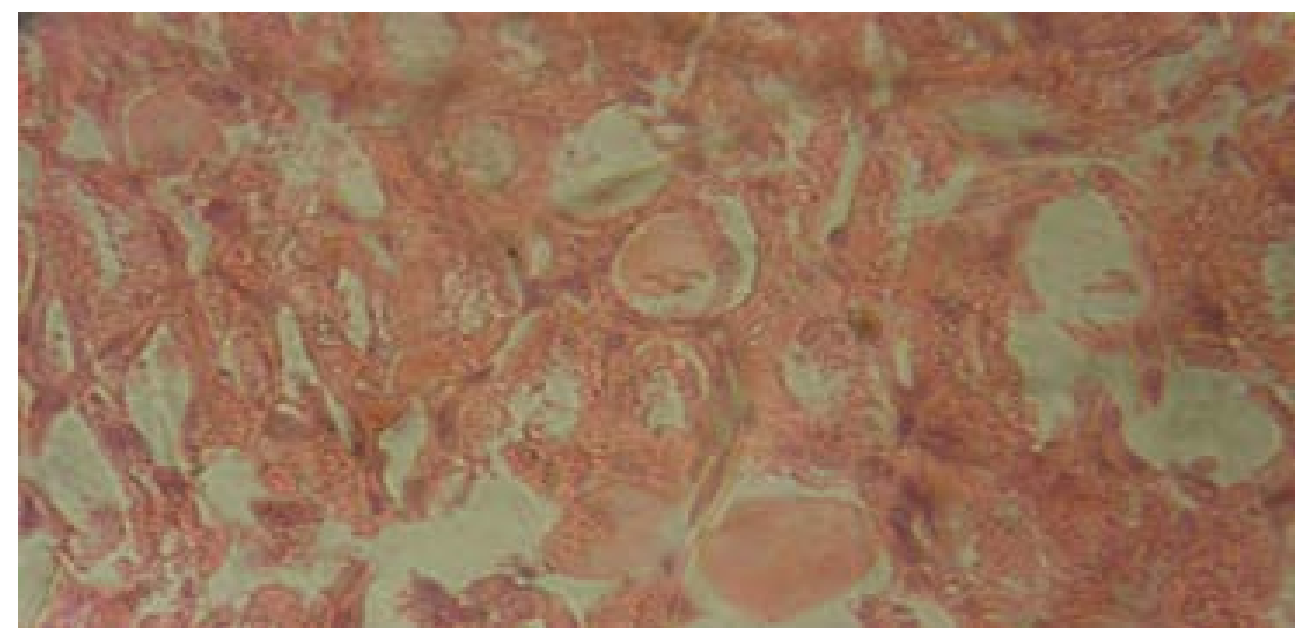

The photomicrogragraph of the kidney of mice passaged with $P$.berghei and treated with chloroquine $10 \mathrm{mg} / \mathrm{kg}$ body weight showing protein casts (Arrow), (H\&E Stain) 
Figure 5 (b) Effect of methyl jasmonate (MJ) $25 \mathrm{mg} / \mathrm{kg} / \mathrm{body}$ weight in liver
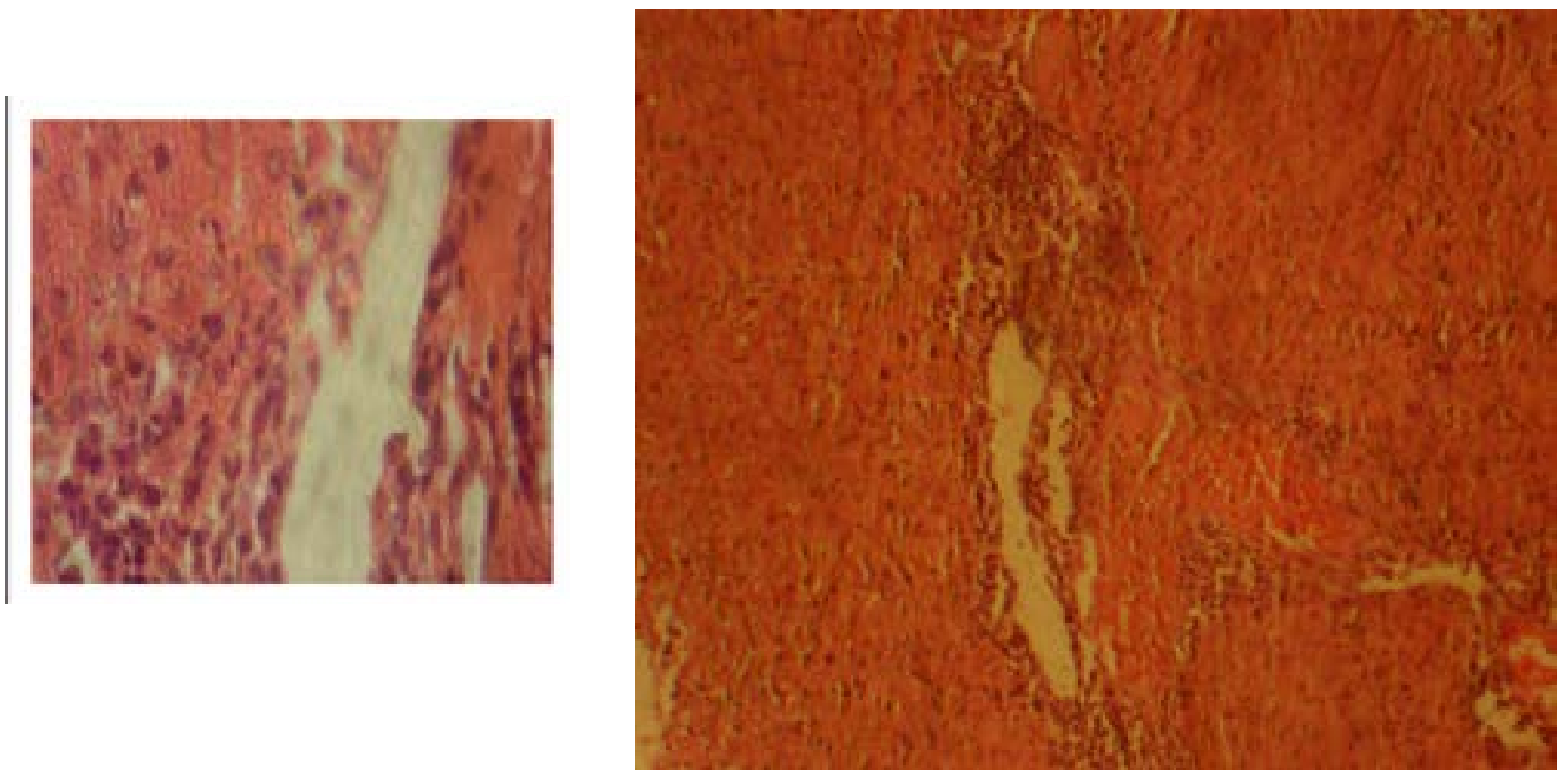

The photomicrograph of the liver of mice passaged with Plasmodium berghei , and treated with $25 \mathrm{mg} / \mathrm{kg}$ body weight MJ,showing perivascular mononuclear cell infiltration(arrow), (H\&E Stain)

Figure 5 (c) Effect of plasmodium berghei in the liver of untreated mice

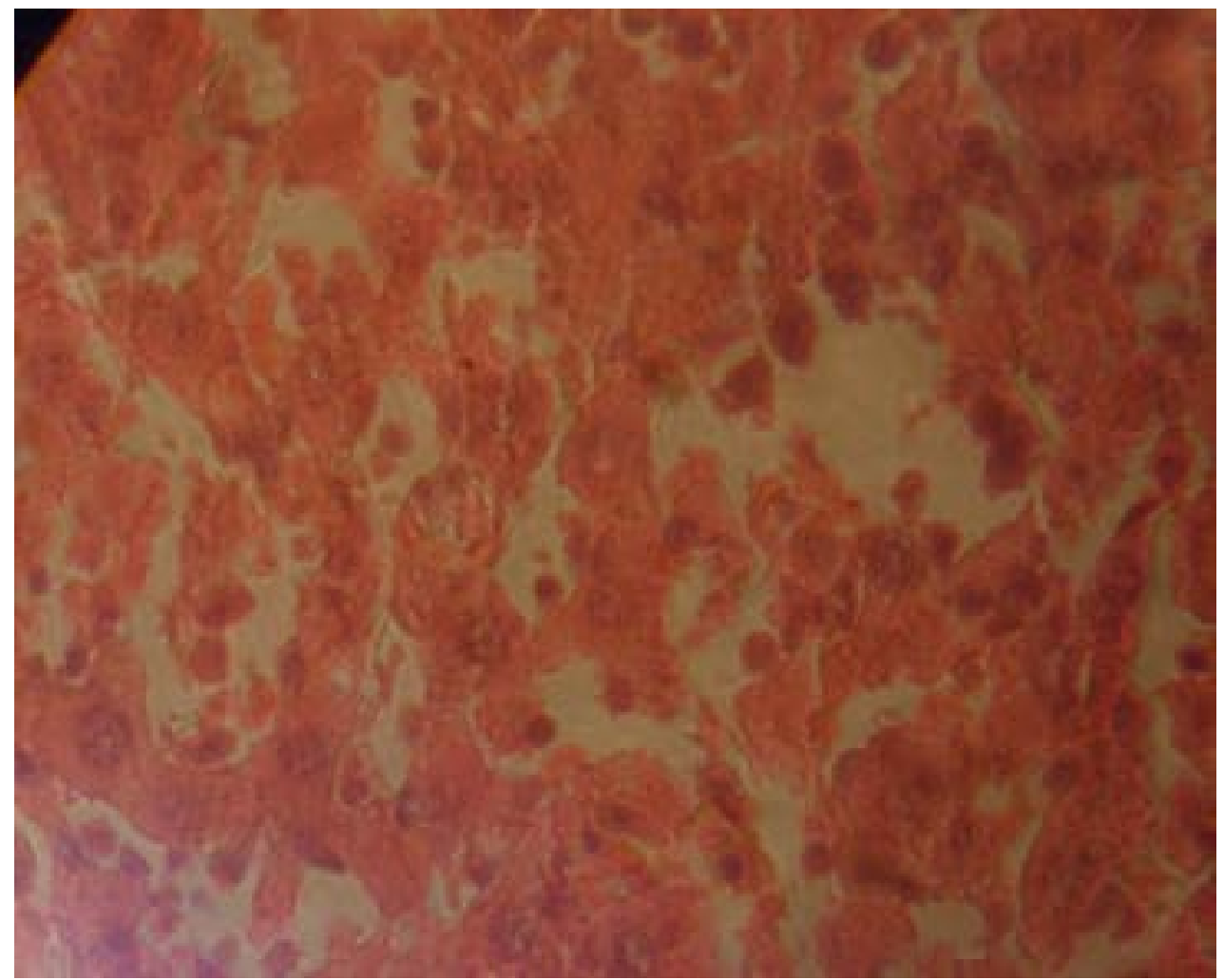

The photomicrogragraph of the liver of mice passaged with P.berghei, without treatment, showing mononuclear cell infiltration and necrosis (arrow), (H\&E Stain) 
Antimalarial drug resistance is a major public health problem, which hinders the control of malaria. There is an urgent need to increase the armamentarium against malaria. As part of this effort, we investigated the antimalarial activity of Methyl Jasmonate in P. berghei infected mice. Results of our studies demonstrated that MJ exhibited a dose-dependent significant reduction in percentage parasitemia from day 3 (post treatment). MJ at a dosage of $50 \mathrm{mg} / \mathrm{kg}$ reduced parasitemia better than 10 and $25 \mathrm{mg} / \mathrm{kg}$ doses. However MJ was less effective when compared to CQ and AE for which considerable reduction in parasitemia was observed by day 2 (post treatment). There was however resurgence in parasitemia in AE treated mice on day 10 (post treatment), which is in agreement with the recrudescence that occurrs to artemisinin monotherapy. ${ }^{10}$

As the percentage parasitemia increased in infected untreated mice, the PCV as expected decreased markedly until the mice died. This is consistent with previous studies. ${ }^{11}$ A decrease in PCV was observed in infected mice treated with $\mathrm{MJ}$ relative to base line PCV before infection while the PCV obtained in uninfected mice administered with $\mathrm{MJ}$ were not affected. P. berghei caused significant increase in cholesterol and triglyceride in infected untreated mice relative to control. Similarly a significant increase in HDL-C and LDL-C was observed in infected untreated mice in comparison to infected treated and uninfected groups . This finding is in concordance with report of Sherman $e t$ al. ${ }^{12}$ that rats infected with $P$. berghei had elevated lipid profiles.

A significant increase in HDL-C and LDL-C occurred in infected and uninfected mice administered with $\mathrm{MJ}$ relative to AE and CQ treated and control groups this may be related to the lipid nature of $\mathrm{MJ} \cdot{ }^{13}$ Liver enzymes (ALT, AST and ALP) are used as markers of liver function and can be used for drug safety evaluation. ${ }^{14,15}$ They are involved in intermediary metabolism and present in high concentration in the liver and are released rapidly into the plasma in cases of acute destruction of tissue as in myocardial infarction or hepatocellular necrosis. ${ }^{15}$ This study demonstrated significantly high activity of ALT, AST and ALP in infected untreated group relative to control which is an indication of hepatocellular function impairement. ${ }^{15} \mathrm{MJ}$ inhibited the increase in AST and ALP level but had no effect on ALT in infected mice. The increase in ALT is the most sensitive marker for liver cell damage while AST and ALP elevation may be caused by other disease conditions apart from hepa- tocellular damage. ${ }^{16} \mathrm{MJ}$ treatment of uninfected mice however caused elevation in ALT, AST and ALP compared with control.

The changes observed in ALT,AST and ALP levels among the uninfected mice might be due to the vehicle used for Methyl Jasmonate (10\% ethanol). Protein cast was observed in the kidney of infected mice treated with CQ. Perivascular mononuclear cell infiltration was observed in the livers of infected treated mice with CQ, MJ 25 and $50 \mathrm{mg} / \mathrm{kg}$, while necrosis was observed in the livers of untreated group. However, livers of infected mice treated with AE were normal, which supports the report of Edington ${ }^{17}$. Gilles et al. ${ }^{18}$ reported that changes in histopathology occur if $P$. berghei penetrate the cerebrum.

\section{Conclusion}

It is concluded that MJ has appreciable antimalarial activity in P. berghei infected mice although reduced relative to AE and CQ. Administration of $\mathrm{MJ}$ in P. berghei infected and uninfected mice showed no significant toxicity in the brain, liver and kidney. MJ will be a good candidate for consideration as a new antimalarial agent. Further in vitro and in vivo evaluation and possible structural modification and drug combination will be required.

\section{Acknowledgement}

We acknowledge Prof. E.A. Bababunmi of ENHICA International for introducing and donating Methyl Jasmonate for this work.

\section{References}

1. WHO. Geneva, World Health Organization, Basco LK. Field application of in vitro assays for the sensitivity of human malaria parasites to antimalarial drugs, 2007.

2. Nwaka S, Ridney RG. Virtual drug discovery and development for neglected diseases through public-private partnerships. Nature Review Drug Discovery 2003; (2):919-928.

3. Balbi V. and A. Devoto,Jasmonate signalling network in Arabidopsis thaliana: crucial regulatory nodes and new physiological scenarios. New phytol. 2008; 177; 301318.

4. Gold SM, Schulz KH, Mladek M, Lang UE, Hellweg R, Reer R,Braumann KM, Heesen C. Basal Serum levels and reactivity of nerve growth factor and brain-derived neurotrophicfactor to standardized acute exercise in 
multiple sclerosis and controls. J. Neuroimmunol. 2003.

5. Fingrut O, Flescher E. Plant stress hormones suppress the proliferation and induce apoptosis in human cancer cells. Leukemia 2000 ;(16): 608-16 PubMed .

6. Samaila D, Ezekwudo DE, Yiman KK, Elegbede JA. Bioactive plant compounds inhibited the proliferation and induced apoptosis in human cancer cell lines, In vitro. TIBETS. 2004 ;(1): 34-42 PubMed .

7. Flescher E. Jasmonates--a new family of anti-cancer agents. Anticancer Drugs. 2005; 16(9): 911 PubMed -6. 8. Elufioye TO, Agbedahunsi JM. Antimalarial activities of Tiothonia diversifolia Asteraceae) and Crossopteryx febrifuga (Rubiaceae) on mice in vivo. J. Ethnopharmacology .2004; 93: 167-171.

9. Friedwald WT, Levy IR, Fredrickson SD. Estimation of the concentration of Low-Density Cholesterol in plasma, without use of the preparative ultracentrifuge .1972 .

10. Dalavaikodihalli NN, Viswanathan AN, Paakkod GV, Pundi R, Govindarajan. Antimicrobial Agents and Chemotherapy 2006; Vol, 50: 1859-1860.
11. Okeola VO, Adaramoye OA, Nneji C.M, Falade CO, Farombi EO, Ademowo OG. Antimalarial and antioxidant activities of methanolic extract of Nigella sativa seeds (black cumin) in mice infected with Plasmodium yoelli nigeriensis. Parasitology Research. 2010.

12. Sherma WI. Microbial Reviews. 1979.

13. Beale MH, Ward LW. Jasmonates: Key players in the plant defence. Nat. Prod. Rep. 1979;15: 533-548.

14. Satyapal SU, Kadam VJ, Ghosh R. Hepatoprotective activity of Livobond, a polyherbal formation against ccl4 induced hepatotoxicity in rats. Int J pharmacology 2008; 4: 472-6.

15. Tienz NW. Fundermentals of clinical chemistry. 6th ed. Philadephia , PA; Saunders 2000;744-5,788 PubMed $-9$.

16. Lee, Mar. Basic skills in interpreting laboratory data. ASPH. 2009; 259.

17. Edington GM .Pathology of malarial in West Africa. Brit. Med. J.1967; 1: 715-721 PubMed .

18. Gilles HM, Hendrickse RG Nephrosis in Nigerian children. Role of plasmodium malarial and effect of antimalarial treatment. Brit, Med.J.1963; 2: 27-31 